\title{
TU/e emonownen

\section{Mesoporous silica nanoparticles with large pores for the encapsulation and release of proteins}

\section{Citation for published version (APA):}

Tu, J., Boyle, A. L., Friedrich, H., Bomans, P. H. H., Bussmann, J., Sommerdijk, N. A. J. M., Jiskoot, W., \& Kros, A. (2016). Mesoporous silica nanoparticles with large pores for the encapsulation and release of proteins. ACS Applied Materials \& Interfaces, 8(47), 32211-32219. https://doi.org/10.1021/acsami.6b11324

DOI:

10.1021/acsami.6b11324

Document status and date:

Published: 30/11/2016

\section{Document Version:}

Accepted manuscript including changes made at the peer-review stage

\section{Please check the document version of this publication:}

- A submitted manuscript is the version of the article upon submission and before peer-review. There can be important differences between the submitted version and the official published version of record. People interested in the research are advised to contact the author for the final version of the publication, or visit the $\mathrm{DOI}$ to the publisher's website.

- The final author version and the galley proof are versions of the publication after peer review.

- The final published version features the final layout of the paper including the volume, issue and page numbers.

Link to publication

\section{General rights}

Copyright and moral rights for the publications made accessible in the public portal are retained by the authors and/or other copyright owners and it is a condition of accessing publications that users recognise and abide by the legal requirements associated with these rights.

- Users may download and print one copy of any publication from the public portal for the purpose of private study or research.

- You may not further distribute the material or use it for any profit-making activity or commercial gain

- You may freely distribute the URL identifying the publication in the public portal.

If the publication is distributed under the terms of Article 25fa of the Dutch Copyright Act, indicated by the "Taverne" license above, please follow below link for the End User Agreement:

www.tue.nl/taverne

Take down policy

If you believe that this document breaches copyright please contact us at:

openaccess@tue.nl

providing details and we will investigate your claim. 
Mesoporous Silica Nanoparticles with Large Pores for the Encapsulation and Release of Proteins

Jing Tu ${ }^{\text {a }}$, Aimee L. Boyle ${ }^{\text {a }}$, Heiner Friedrich ${ }^{\text {b }}$, Paul H. H. Bomans ${ }^{\text {b }}$, Jeroen Bussmann ${ }^{\text {a, c }}$, Nico A. J. M. Sommerdijk ${ }^{b}$, Wim Jiskoot ${ }^{d^{*}}$, Alexander Kros ${ }^{a^{*}}$

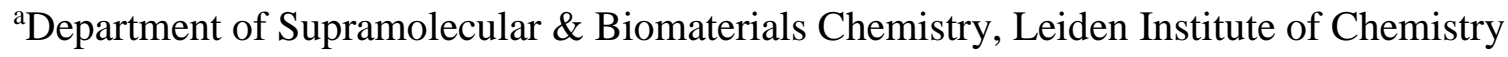
(LIC), Leiden University, P.O. Box 9502, 2300 RA Leiden, The Netherlands

${ }^{\mathrm{b}}$ Laboratory of Materials and Interface Chemistry \& Center of Multiscale Electron Microscopy, Department of Chemical engineering and Chemistry, and Institute for Complex Molecular Systems, Eindhoven University of Technology, P.O. Box 513, 5600 MB Eindhoven, The Netherlands

cLeiden Institute of Biology, Gorlaeus Laboratories, Leiden University, P.O. Box 9502, Leiden, 2300 RA, The Netherlands

${ }^{\mathrm{d} D i v i s i o n}$ of Drug Delivery Technology, Cluster BioTherapeutics, Leiden Academic Centre for Drug Research (LACDR), Leiden University, P.O. Box 9502, 2300 RA Leiden, The Netherlands 


\section{ACS Applied Materials \& Interfaces}

\section{Abstract}

Mesoporous silica nanoparticles (MSNs) have been explored extensively as solid supports for proteins in biological and medical applications. Small $(<200 \mathrm{~nm})$ MSNs with ordered large pores $(>5 \mathrm{~nm}$ ), capable of encapsulating therapeutic small molecules suitable for delivery applications in vivo, are rare however. Here we present small, elongated, cuboidal, MSNs with average dimensions of $90 \times 43 \mathrm{~nm}$ that possess disk-shaped cavities, stacked on top of each other, which run parallel to the short axis of the particle. Amine-functionalization was achieved by modifying the MSN surface with 3-aminopropyltriethoxysilane or 3-[2-(2aminoethylamino)ethylamino] propyltrimethoxysilane (AP-MSNs and AEP-MSNs) and were shown to have similar dimensions to the non-functionalized MSNs. The dimensions of these particles, and their large surface areas as measured by nitrogen adsorption-desorption isotherms, make them ideal scaffolds for protein encapsulation and delivery. We therefore investigated the encapsulation and release behavior for seven model proteins ( $\alpha$-lactalbumin, ovalbumin, bovine serum albumin, catalase, hemoglobin, lysozyme and cytochrome c). It was discovered that all types of MSNs used in this study allow rapid encapsulation, with a high loading capacity, for all proteins studied. Furthermore, the release profiles of the proteins were tunable. The variation in both rate and amount of protein uptake and release was found to be determined by the surface chemistry of the MSNs, together with the isoelectric point $(\mathrm{pI})$, and molecular weight of the proteins, as well as by the ionic strength of the buffer. These MSNs with their large surface area and optimal dimensions, provide a scaffold with a high encapsulation efficiency and controllable release profiles for a variety of proteins, enabling potential applications in fields such as drug delivery and protein therapy.

Keywords: mesoporous silica nanoparticles, protein loading, protein release, nanomedicine, sol-gel, drug delivery 


\section{ACS Applied Materials \& Interfaces}

\section{Introduction}

Proteins participate in a variety of vital processes in the body, ${ }^{1}$ and are therefore used as therapeutic agents in a diverse range of biomedical applications, ${ }^{2-4}$ such as cancer therapy, ${ }^{5-6}$ vaccination, ${ }^{7-8}$ and protein therapy. ${ }^{9-10}$ Several barriers have to be overcome for efficient protein delivery however, as most native proteins are membrane impermeable due to electrostatic repulsion, and are prone to degradation or inactivation processes in bodily fluids. ${ }^{1}$ Over the last decades, various nanocarriers such as lipid-based assemblies, ${ }^{11}$ gold nanoparticles ${ }^{12}$ and polymeric nanoparticles, ${ }^{13}$ have been developed to overcome these barriers.

Mesoporous silica nanoparticles (MSNs) are a class of molecules that have attracted a lot of attention in the small molecule delivery field, due to their multitude of desirable properties. They possess an open-pore structure; the sizes of the pores and of the MSNs themselves can be controlled synthetically. ${ }^{14-16}$ Furthermore, the silanol-containing surface can be readily functionalized, ${ }^{17-21}$ enabling modification with targeting molecules such as folate or hyaluronic acid to enhance cellular uptake, ${ }^{22-24}$ and permitting the adsorption of various proteins with different isoelectric points (pI). ${ }^{18,25}$ Due to their structure, MSNs protect proteins from premature degradation in body fluids, thereby increasing the efficiency of protein delivery in vivo, thus reducing renal filtration. ${ }^{1}$ This combination of properties means MSNs have exhibited potential as a non-invasive and biocompatible platform for protein delivery, ${ }^{26-28}$ especially in the fields of enzyme therapies, ${ }^{9-10}$ vaccination, ${ }^{7-8,29}$ and imaging. ${ }^{30}$ Since MSNs are much smaller than eukaryotic cells, they can facilitate the transport of proteins into the cytosol via an endocytosis pathway and subsequent endosomal escape. ${ }^{31-32}$

Numerous synthetic protocols for the preparation of MSNs have been developed with the aim of controlling the size and morphology of these nanoparticles. ${ }^{33-36}$ Encapsulating proteins in MSNs is still challenging however, and only a few publications concerning the design of MSNs with a morphology that enables the effective encapsulation of a broad range of proteins 


\section{ACS Applied Materials \& Interfaces}

are available. ${ }^{37-38}$ Typically, proteins are only adsorbed onto the external surface of MSNs due to the small pore diameter $(<3 \mathrm{~nm})$ preventing the proteins from entering the MSNs' interior pores. ${ }^{7}{ }^{39}$ Proteins adsorbed at the MSNs' outer surface do not make use of the protective environment inside the MSNs, nor do they utilize the large internal surface area presented by the pores. ${ }^{16,40}$ Thus, limitations in generating small $(<200 \mathrm{~nm}$ in diameter $)$ MSNs with sufficient pore sizes $(>5 \mathrm{~nm})$ to encapsulate proteins or other biomacromolecules is one of the major hurdles for "comfortably" hosting large molecules. ${ }^{26,41-43}$ In order to solve this protein inaccessibility issue, MSNs with a large pore size have been synthesized. However, the diameter of the majority of these particles is $1-2 \mu \mathrm{m}$ and so these are less suited for in vivo delivery applications. Studies have shown that particle sizes between 50 and $200 \mathrm{~nm}$ are preferred for endocytic uptake. ${ }^{31,44-45}$ Therefore, monodisperse MSNs with a particle size in the 50-200 $\mathrm{nm}$ range, controllable surface chemistry, and a large pore size $(>5 \mathrm{~nm})$ are desired. ${ }^{37,42}$

Building upon previous methods, ${ }^{34,46-48}$ we designed a facile synthetic route to produce MSNs that are able to effectively encapsulate and release a variety of proteins. To obtain the desired large pores in a sub-200 nm particle, a double-surfactant system consisting of a high molecular weight block copolymer (Pluronic P123), 34, 37, 46 and fluorocarbons, ${ }^{34,49}$ was employed as the structure-directing template. The swelling agent 1,3,5-trimethylbenzene (TMB) was added to expand the diameter of the pores. ${ }^{34,46}$ These MSNs were synthesized as stable colloidal suspensions with a narrow size distribution and channels aligned parallel to the short axis. This mesostructure favors efficient mass transfer, ${ }^{50}$ as it possesses a high density of entrances enabling rapid and efficient encapsulation of proteins. ${ }^{41}$

The obtained MSNs bear a net negative charge, ${ }^{35,40}$ at physiological $\mathrm{pH}$. To study the effect of the silica surface charge on protein encapsulation, cationic MSNs were prepared by a post-synthesis grafting method involving the amine-containing silanes (3aminopropyl)triethoxysilane (APTES) and 3-[2-(2-aminoethylamino)ethylamino] 


\section{ACS Applied Materials \& Interfaces}

propyltrimethoxysilane (AEPTMS). This modification generated positively charged MSNs at physiological $\mathrm{pH}$, designated as AP-MSNs and AEP-MSNs, respectively.

To illustrate the potential of these new, large-pore MSNs as protein carriers, the encapsulation and release of a range of model proteins ${ }^{25,51-54}$ with different molecular weights (Mw) and isoelectric points (pI) was studied, revealing that the MSNs' surface charge controls the protein encapsulation efficiency. The release profiles of the proteins from these large-pore MSNs were subsequently examined, and it was additionally confirmed that the structure of the released proteins was not altered.

\section{Materials and Methods}

\subsection{Materials}

Pluronic P123 $\left(\mathrm{EO}_{20} \mathrm{PO}_{70} \mathrm{EO}_{20}, \mathrm{M}_{\mathrm{n}} \sim 5800 \mathrm{~g} / \mathrm{mol}\right)$, tetraethyl orthosilicate (TEOS, $\geq 98 \%$ ), hydrochloric acid (HCl), mesitylene, 3-aminopropyltriethoxysilane (APTES), 3-[2-(2aminoethylamino)ethylamino] propyltrimethoxysilane (AEPTMS), 1,3,5-trimethylbenzene (TMB), $\alpha$-lactalbumin from bovine milk (LAC), albumin from chicken egg white (OVA), bovine serum albumin (BSA), catalase from bovine liver (CAT), hemoglobin from bovine blood $(\mathrm{Hb})$, cytochrome c from equine heart (CYT) and lysozyme from chicken egg white (LYS) were purchased from Sigma-Aldrich and used as received. Fluorocarbon surfactant FC-4 was purchased from Yick-Vic Chemicals \& Pharmaceuticals (HK) Ltd, China. Milli-Q water (18.2 M $\Omega / \mathrm{cm}$, Millipore Co., USA) was used throughout the experiments. The composition of the phosphate buffered saline (PBS) used was: $\mathrm{K}_{2} \mathrm{HPO}_{4}(14.99 \mathrm{mM}), \mathrm{KH}_{2} \mathrm{PO}_{4}$ (5 mM), and $\mathrm{NaCl}(150.07 \mathrm{mM})$, with an ionic strength of $270 \mathrm{mM}$. The phosphate buffer (PB) with an ionic strength of $12 \mathrm{mM}$ was prepared by mixing $\mathrm{Na}_{2} \mathrm{HPO}_{4}(1 \mathrm{mM})$ and $\mathrm{NaH}_{2} \mathrm{PO}_{4}(1 \mathrm{mM})$ at molar ratio of 5:2. The PB with an ionic strength of $166 \mathrm{mM}$ was prepared by adding $0.9 \% \mathrm{NaCl}$ into previously described $\mathrm{PB}$ with an ionic strength of $12 \mathrm{mM}$. The $\mathrm{pH}$ values were adjusted to 7.4 . 


\section{ACS Applied Materials \& Interfaces}

\subsection{Preparation of large-pore MSNs and functionalized MSNs}

MSNs were synthesized as follows. $0.5 \mathrm{~g}$ of surfactant Pluronic P123 and $1.4 \mathrm{~g}$ of FC-4 were dissolved in $80 \mathrm{~mL}$ of $\mathrm{HCl}(0.02 \mathrm{M})$, followed by the introduction of $0.48 \mathrm{~mL}$ of TMB. After stirring for $6 \mathrm{~h}, 2.14 \mathrm{~mL}$ of TEOS was added dropwise. The resulting mixture was stirred at $30{ }^{\circ} \mathrm{C}$ for $24 \mathrm{~h}$ and transferred to an autoclave at $120{ }^{\circ} \mathrm{C}$ for 2 days. Finally, the solid product was isolated by centrifugation, and washed with ethanol and water. The organic template was completely removed by calcination at $550{ }^{\circ} \mathrm{C}$ for $5 \mathrm{~h}$.

The MSNs were functionalized with amine-containing groups through a postmodification procedure. ${ }^{55-56}$ For AP-MSNs, $100 \mathrm{mg}$ of MSNs were suspended in $10 \mathrm{~mL}$ of ethanol and $0.4 \mathrm{~mL}$ of APTES was added. The mixture was refluxed at $77{ }^{\circ} \mathrm{C}$ for $10 \mathrm{~h}$ with stirring. The resulting particles were collected by centrifugation (13000 rpm, $5 \mathrm{~min}$ ), washed thoroughly with ethanol and water three times, and freeze-dried. For AEP-MSNs, $100 \mathrm{mg}$ of MSNs were incubated with $4 \mathrm{~mL}$ of $20 \mathrm{wt} \%$ AEPTMS in ethanol, overnight at room temperature. The AEP-MSNs were purified by centrifugation (13000 rpm, $5 \mathrm{~min}$ ) and washed with ethanol and water three times to remove unreacted AEPTMS, and freeze-dried.

\subsection{Protein encapsulation studies}

A protein stock solution $(0.5 \mathrm{mg} / \mathrm{mL})$ was prepared in phosphate buffer $(1 \mathrm{mM}, \mathrm{pH} 7.4)$. MSNs, AP-MSNs, and AEP-MSNs (2 mg/mL), were sonicated (10 min) and dispersed in the same buffer. In a typical procedure, $0.5 \mathrm{~mL}$ of protein stock solution was mixed with $0.5 \mathrm{~mL}$ of MSNs, AP-MSNs or AEP-MSNs suspension and incubated in an Eppendorf mixer (400 rpm, $25^{\circ} \mathrm{C}$ ). After incubation for $20 \mathrm{~min}$, protein-loaded particles (MSNs, AP-MSNs and AEP-MSNs) were collected by centrifugation (13000 rpm, $5 \mathrm{~min}$ ) and separated from the non-encapsulated protein, which remained in the supernatant. The encapsulation efficiency (EE\%) was determined by measuring the difference in concentration of the protein in the supernatant before and after loading. The concentration of protein was determined using a standard calibration curve of the corresponding protein. The intrinsic fluorescence intensity 


\section{ACS Applied Materials \& Interfaces}

and absorbance of the proteins were measured using Greiner 96-well flat-bottom black, and Greiner 96-well flat-bottom transparent, microplates respectively in a plate reader (Tecan infinite M1000). For LAC, OVA, BSA, CAT and LYS, the standard curves were based on the intrinsic fluorescence intensity (excitation wavelength $=280 \mathrm{~nm}$ and emission wavelength $=$ $320 \mathrm{~nm})$ as a function of concentration $(0-500 \mu \mathrm{g} / \mathrm{mL})$. For $\mathrm{Hb}$ and CYT, the calibration curves were based on the absorbance at $405 \mathrm{~nm}$ and $412 \mathrm{~nm}$ respectively, as a function of concentration $(0-500 \mu \mathrm{g} / \mathrm{mL})$. The EE\% and loading capacity $(\mathrm{mg} / \mathrm{g})$ were calculated as shown in Equation 1 and 2:26,57

$\mathrm{EE} \%=\frac{t_{\text {protein }}-f_{\text {protein }}}{t_{\text {protein }}} \times 100 \%$

Loading capacity $(\mathrm{mg} / \mathrm{g})=\frac{t_{\text {protein }}(\mathrm{mg})-f_{\text {protein }}(\mathrm{mg})}{\text { amount of MSNs }(\mathrm{g})}$

Where $t_{\text {protein }}$ is the total amount of protein, and $f_{\text {protein }}$ is the amount of free protein.

\subsection{Protein release studies}

The in vitro release of encapsulated proteins, and the effect of ionic strength on the release profiles, was determined by suspending the protein-loaded MSNs in $1 \mathrm{~mL}$ of phosphate buffer of different ionic strengths (12 mM, $166 \mathrm{mM}$ and $270 \mathrm{mM})$ at a final MSN concentration of $1 \mathrm{mg} / \mathrm{mL}$. All suspensions were placed in an Eppendorf mixer (400 rpm, $37{ }^{\circ} \mathrm{C}$ ). The amount of released protein was determined by removing the supernatant after centrifugation (13000 rpm, $5 \mathrm{~min})$ and replacing it with clean buffer $(1 \mathrm{~mL})$ at specified time points. The amount of protein in the supernatant was measured using a Tecan infinite M1000 plate reader (using the settings described in section 2.3). All measurements were performed in triplicate. CD spectra of the proteins before and after release were measured using a Jasco J815 spectropolarimeter. Spectra were collected from $260-190 \mathrm{~nm}$, at $25{ }^{\circ} \mathrm{C}$ to determine whether encapsulation and subsequent release of the proteins had any effect on their secondary structure.

\subsection{Particle analysis}




\section{ACS Applied Materials \& Interfaces}

The porous structure of the as-prepared MSNs was characterized using transmission electron microscopy (TEM) operated at $70 \mathrm{kV}$ (TEM, JEOL 1010, USA). (Cryo-) electron tomography was performed in bright-field mode using zero-loss energy filtering with $20 \mathrm{eV}$ energy window on the TU/e cryoTITAN (FEI, FEG, $300 \mathrm{kV}$, Gatan Energy filter). Images of the tilt-series were collected either dry at room temperature or under cryogenic conditions with the particles suspended in vitrified water over an angular range of $\pm 65^{\circ}$ at 2 degree increments and with a nominal underfocus of $-200 \mathrm{~nm}$ (dry) or $-5 \mu \mathrm{m}$ (cryo). Due to the beam sensitivity of the material, the total accumulated dose over the entire tilt-series was kept below $100 \mathrm{e}^{-} / \AA^{2}$. Alignment by fiducial gold particles, 3D reconstruction and denoising using nonlinear anistropic diffusion was carried out in IMOD. Visualization was performed in Avizo. Surface analysis of the MSNs was performed by measuring nitrogen-sorption isotherms at $77 \mathrm{~K}$ with a Micromeritics TrisStar II 3020 as the analyzer. As a pretreatment, MSNs were outgassed at $300{ }^{\circ} \mathrm{C}$ for $16 \mathrm{~h}$ under vacuum (below $0.15 \mathrm{mbar}$ ), while the other samples (AP-MSNs, AEP-MSNs, and protein-loaded MSNs) were outgassed at $25{ }^{\circ} \mathrm{C}$ for $16 \mathrm{~h}$. The specific surface areas were calculated using the Brunauer-Emmett-Teller (BET) method. The pore size distribution was calculated from the desorption branch of the isotherm by the Barrett-Joyner-Halenda (BJH) method. ${ }^{58}$ The hydrodynamic diameter and zeta-potential of the MSNs were measured with a Malvern Nano-ZS instrument.

\section{Results and discussion}

\subsection{Synthesis and characterization of MSNs, AP- and AEP-MSNs}

Existing literature details how amphiphilic block copolymers such as Pluronic P123, ${ }^{37,46}$ act as organic structure-directing agents, and co-solvent organic molecules (e.g. TMB) ${ }^{59-60}$ can be used as swelling agents to obtain MSNs with large pores. This technique was replicated here and, in addition, the cationic fluorocarbon surfactant FC-4 was utilized to confine the diameter of the MSNs. ${ }^{34}$ Additionally, a hydrothermal treatment, similar to the 
procedure reported by $\mathrm{Han},,^{34,61}$ but with a higher temperature $\left(120^{\circ} \mathrm{C}\right)$ and a longer reaction time $(48 \mathrm{~h})$ was employed to improve mesoscopic regularity and to further extend pore size. ${ }^{46}$, $48,62-63$
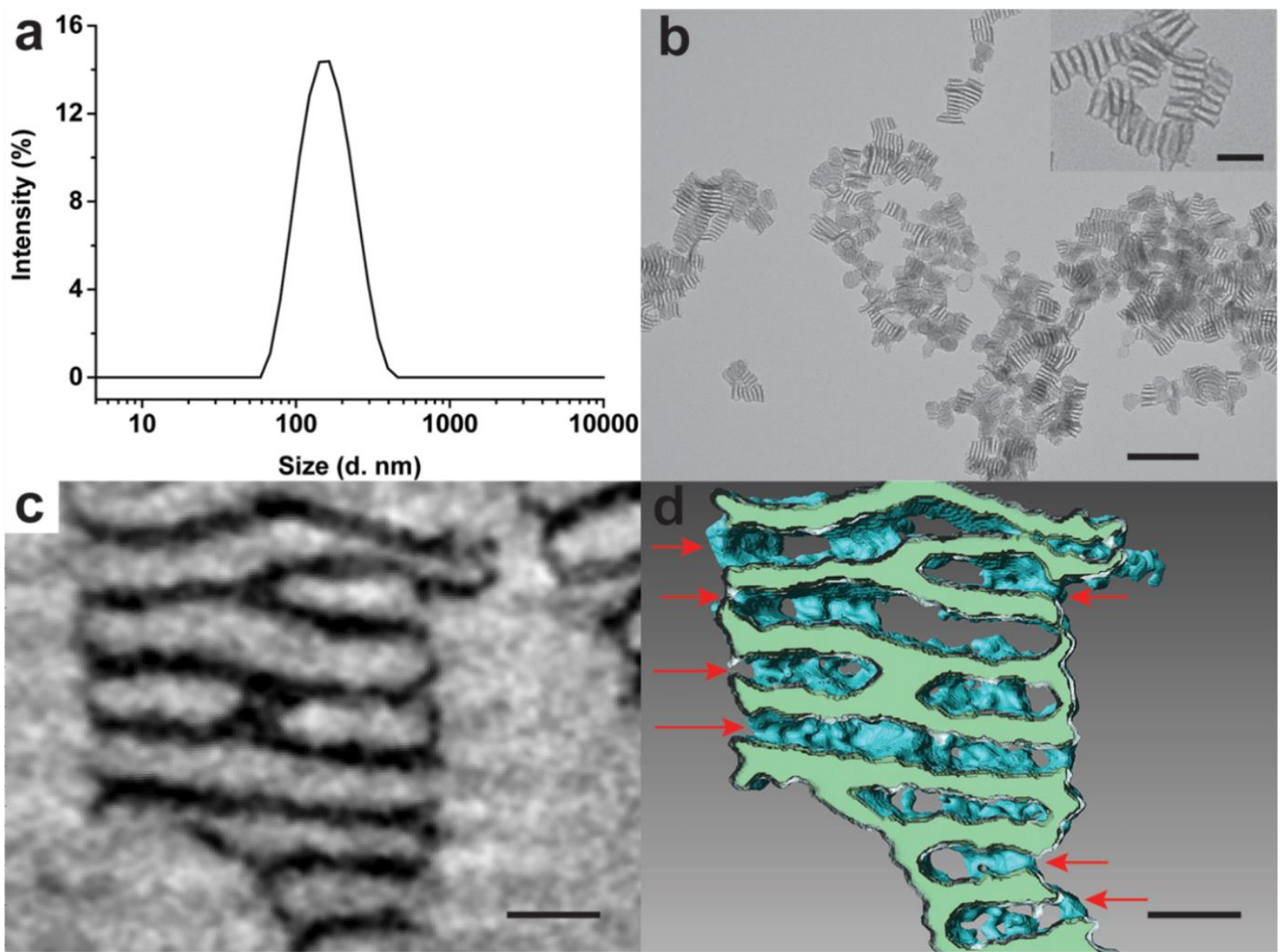

Figure 1. (a) Hydrodynamic diameter by DLS; (b) TEM image of MSNs, scale bar $=200 \mathrm{~nm}$, insert figure with scale bar $=50 \mathrm{~nm}$, (c) and (d) electron tomography results showing crosssection through reconstruction (pores that connect cavities with the environment are indicated by arrows) and 3D rendering of silica surface (cut to expose the interior), scale bar $=25 \mathrm{~nm}$.

Dynamic light scattering (DLS) measurements revealed MSNs with a unimodal distribution that possessed an average hydrodynamic diameter of $146 \mathrm{~nm}$ (Figure 1a). The morphology and mesoporous structure of the MSNs was visualized by TEM (Figure 1b). Analysis of the TEM images revealed the MSNs had lengths of $90 \pm 20 \mathrm{~nm}$ and widths of 43 $\pm 7 \mathrm{~nm}$, giving them an elongated cuboidal-like geometry. These sizes were slightly smaller 


\section{ACS Applied Materials \& Interfaces}

than those determined by DLS, since TEM provides the size distribution of dehydrated particles and DLS measurements yield an average hydrodynamic diameter of the particles in solution. ${ }^{64}$ The MSNs were found to possess large channels with an average size of $10 \pm 1 \mathrm{~nm}$ (measurements from 150 particles). These channels run parallel to the short axis of the MSNs.

Next, a 3D-reconstruction of the MSNs was obtained by (cryo-) electron tomography (see supporting

movie 


\section{(C) $14 \quad D \mid$ AD $=0$}

). This revealed the MSNs possessed disk-shaped cavities, or channels, stacked on top of each

other, which run parallel to the short axis of the particle, consistent with the TEM observations (Figure 1c\&d). 


\section{ACS Applied Materials \& Interfaces}

To further characterize the channels within the MSNs, nitrogen sorption measurements were performed. The MSNs exhibit characteristic type IV isotherms with type- $\mathrm{H}_{1}$ hysteresis loops 46,65 in nitrogen sorption measurements, indicative of the presence of channel-like mesopores (Figure 2a). The average diameter of the channels inside these MSNs was calculated to be 9-11 nm (Figure 2b), consistent with the result obtained by TEM. The MSNs were calculated to have a large specific surface area of $506 \mathrm{~m}^{2} / \mathrm{g}$ (Table 1).
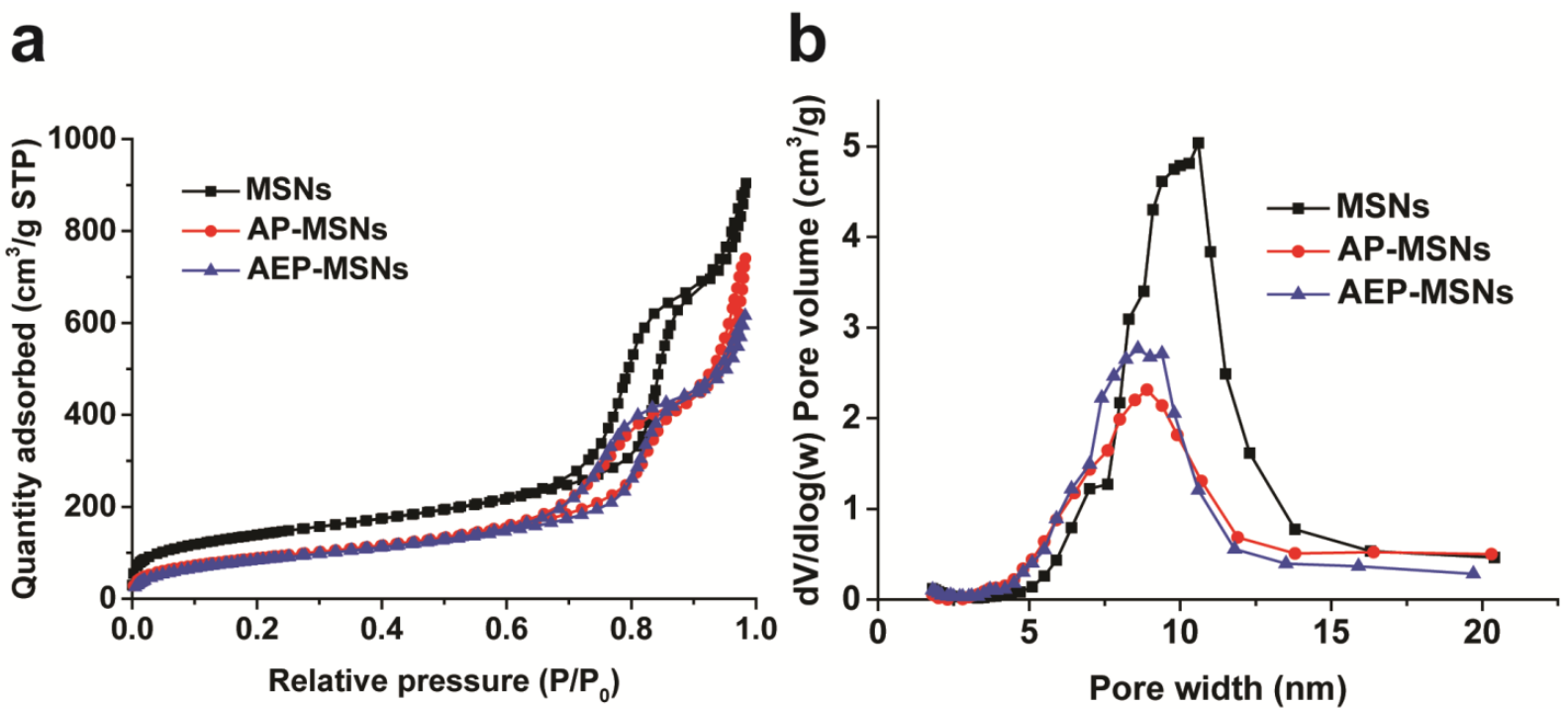

Figure 2. (a) Nitrogen adsorption-desorption isotherms and; (b) corresponding pore size distributions of MSNs, AP-MSNs and AEP-MSNs.

Amino-modified MSNs, termed AP- and AEP-MSNs, were synthesized by reacting the MSNs with APTES, and AEPTMS respectively. These modified MSNs also exhibited type IV isotherms with type- $\mathrm{H}_{1}$ hysteresis loops (Figure $2 \mathrm{a}$ ), indicating functionalization of the surface of the MSNs with amine groups did not perturb the structure. The presence of amino groups does reduce the specific surface area to $328 \mathrm{~m}^{2} / \mathrm{g}$ and $318 \mathrm{~m}^{2} / \mathrm{g}$ for AP-MSNs and AEP-MSNs respectively (Table 1). This is in accordance with the slightly reduced pore diameters of APand AEP-MSNs, which are both calculated to be $9 \pm 1 \mathrm{~nm}$ (Figure $2 \mathrm{~b} \&$ Table 1 ), which is still larger than the geometric size of most proteins.

Table 1. Physical characteristics of MSNs, AP-MSNs and AEP-MSNs 


\begin{tabular}{cccc}
\hline Sample & $\begin{array}{c}\text { BET specific } \\
\text { surface area }\left(\mathrm{m}^{2} / \mathrm{g}\right)\end{array}$ & $\begin{array}{c}\text { Specific channel } \\
\text { volume }\left(\mathrm{cm}^{3} / \mathrm{g}\right)\end{array}$ & $\begin{array}{c}\text { Average channel } \\
\text { diameter }(\mathrm{nm})^{\mathrm{a}}\end{array}$ \\
\hline MSNs & 506 & 1.01 & $10 \pm 1$ \\
AP-MSNs & 328 & 0.68 & $9 \pm 1$ \\
AEP-MSNs & 318 & 0.71 & $9 \pm 1$
\end{tabular}

${ }^{\mathrm{a} C a l c u l a t e d}$ from the desorption branch of the $\mathrm{N}_{2}$ sorption isotherms based on the BJH method.

\subsection{Protein loading studies}

To test the potential of these MSNs for protein-based delivery applications we studied the encapsulation and release of seven model proteins with different molecular weights, geometric sizes, shapes, and $\mathrm{pI}$ values. These proteins were selected due to the wide variety of physical properties they collectively presented, (Table 2), and because of their biological applications, for example: ovalbumin has been studied for its antigenic properties; ${ }^{7-8}$ catalase is an important antioxidant; ${ }^{9-10}$ hemoglobin is a well-characterised oxygen carrier; ${ }^{57,66}$ and cytochrome c has been known to induce apoptosis. ${ }^{59,67}$

Table 2. List of encapsulated proteins and their properties

\begin{tabular}{ccccc}
\hline Protein & Classification $^{\mathrm{a}}$ & Mw/kDa & Size $^{\mathrm{b}}(\mathrm{nm})$ & $\mathrm{pI}$ \\
\hline LAC & glycoprotein & 14.2 & $2.3 \times 2.6 \times 4$ & 4.5 \\
OVA & allergen & 42.7 & $4 \times 5 \times 7$ & 4.9 \\
BSA & transport protein & 66.5 & $5 \times 5 \times 9$ & 4.9 \\
CAT & oxidoreductase & 250 & $7 \times 8 \times 10$ & 5.8 \\
Hb & oxygen binding & 64.5 & $5.3 \times 5.4 \times 6.5$ & 6.8 \\
LYS & hydrolase & 14.3 & $3 \times 3 \times 4.5$ & $10-10.5$ \\
CYT & electron transport & 12.4 & $2.6 \times 3.2 \times 3.3$ & 11.35 \\
\hline
\end{tabular}

${ }^{\mathrm{a}}$ The classification and residue count of these proteins comes from the protein data bank (PDB, 
www.rcsb.org). PDB codes: LAC, 1HFX; OVA, 1VAC; BSA, 4F5S; CAT, 1TGU; Hb, 2QSS; LYS, 4YM8; CYT, 2N3B.

${ }^{\mathrm{b}}$ Geometric dimensions given by published literature. ${ }^{40,68-70}$

Proteins were mixed with MSNs, AP- and AEP-MSNs in a 1:4 (protein:MSN) weight ratio. Figure 3a shows the encapsulation efficiency (EE\%) of these proteins at physiological $\mathrm{pH}$. The encapsulation process was found to be very rapid, with over $95 \%$ encapsulation efficiency being achieved within twenty minutes for all proteins.
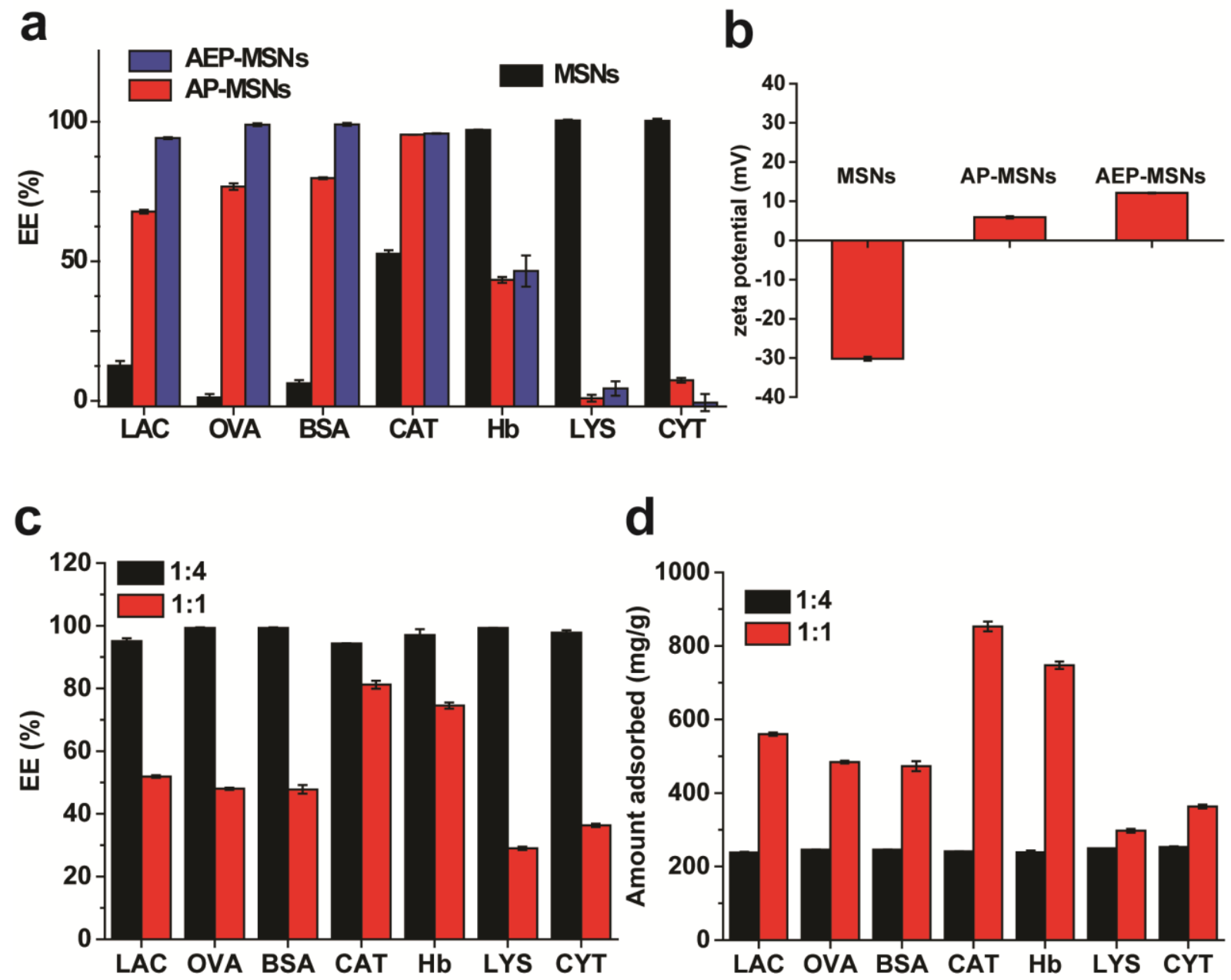

Figure 3. (a) EE\% of seven proteins in MSNs (black bars), AP-MSNs (red bars), and AEPMSNs (blue bars), the initial weight ratio for encapsulation between protein and particles was 1:4 (250 mg of protein/1 g particles); (b) zeta potential of MSNs, AP-MSNs and AEP-MSNs in $1 \mathrm{mM} \mathrm{PB}, \mathrm{pH} 7.4$; (c) Encapsulation efficiency (EE\%) of seven proteins (LAC, OVA, BSA 


\section{ACS Applied Materials \& Interfaces}

and CAT in AEP-MSNs, and Hb, LYS and CYT in MSNs), and (d) the corresponding loading capacity $(\mathrm{mg} / \mathrm{g})$ for all proteins. The weight ratio for encapsulation between protein and MSNs is 1:4 (black bars) and 1:1 (red bars). Conditions for encapsulation of all proteins: 1 $\mathrm{mM}$ PB, ionic strength $12 \mathrm{mM}, 25^{\circ} \mathrm{C}, 20 \mathrm{~min}$.

The charges of the MSNs, AP-MSNs and AEP-MSNs vary due to the surface chemistry of the particles. Zeta-potential analysis (Figure 3b), revealed a negative surface charge for MSNs (-30.2 mV), but a positive charge for both AP- and AEP-MSNs $(+5.9 \mathrm{mV}$ and +12.1 $\mathrm{mV}$, respectively). This charge affects the extent of protein encapsulation; for proteins with a negative surface charge (LAC, OVA, BSA and CAT), encapsulation in positively charged AP- and AEP-MSNs was more efficient when compared to encapsulation in unmodified MSNs. This was especially relevant with AEP-MSNs, where the encapsulation efficiency for all four of these proteins reached more than $95 \%$. It is therefore evident that the amount of LAC, OVA, BSA and CAT encapsulated can be increased by the introduction of positively charged amine moieties onto the MSNs surface. Conversely, for the positively charged proteins LYS and CYT the amount encapsulated decreases when AP- or AEP-MSNs are employed. The observed results indicate that electrostatic interactions are likely to be the main driving force for protein encapsulation. ${ }^{51,71-72}$ It is also interesting to note that CAT (250 $\mathrm{kDa}, c a .10 \mathrm{~nm}$ diameter ${ }^{52}$ can be encapsulated into the mesopore network despite the fact that the pore size is similar to that of protein. ${ }^{73}$ Interestingly, $\mathrm{Hb}(\mathrm{pI}=6.8)$ is still negatively charged when dissolved in phosphate buffer at $\mathrm{pH}$ 7.4. Still, the EE\% of $\mathrm{Hb}$ reached $97 \%$, while for AP-MSNs the EE\% was $43 \%$ and for AEP-MSNs, 47\%. For positively charged proteins (LYS and CYT), a high encapsulation efficiency (97\% and 98\% respectively), was obtained with unmodified MSNs while the encapsulation in AP-MSNs and AEP-MSNs was limited due to electrostatic repulsion.

Considering the initial weight ratio between the proteins and MSNs (1:4), and the EE\%, 


\section{ACS Applied Materials \& Interfaces}

these results clearly showed that MSNs (with an appropriate surface charge) can act as nanocarriers to efficiently encapsulate a wide variety of proteins (Mw 12.3-250 kDa, pI 4.511.3) with a loading capacity of at least $25 \mathrm{wt} \%(250 \mathrm{mg} / \mathrm{g})$. When the initial weight ratio between the proteins and MSNs was increased (1:1), the EE\% decreased but the total amount of protein encapsulated increased. For example, the loading capacity of CAT into AEP-MSNs increased from $241.7 \pm 0.4 \mathrm{mg} / \mathrm{g}$ to $852.9 \pm 13.2 \mathrm{mg} / \mathrm{g}$, while for $\mathrm{Hb} 239.1 \pm 4.6 \mathrm{mg} / \mathrm{g}$ was encapsulated at the $1: 4$ ratio, but this rose to $747.5 \pm 10.0 \mathrm{mg} / \mathrm{g}$ when a 1:1 ratio was used. For LAC an increase from $238.0 \pm 2.3 \mathrm{mg} / \mathrm{g}$ to $560.0 \pm 4.4 \mathrm{mg} / \mathrm{g}$ was observed (Figure $3 \mathrm{c}$ and $3 \mathrm{~d}$ ). The large pore size is advantageous, especially for proteins with a high molecular weight and hence a large size. Upon protein encapsulation, both the surface area and pore diameter of the MSNs decreased, showing that the protein molecules had been encapsulated within the channels of the MSNs (Figure 4\&Table S1). ${ }^{37}$ 
a

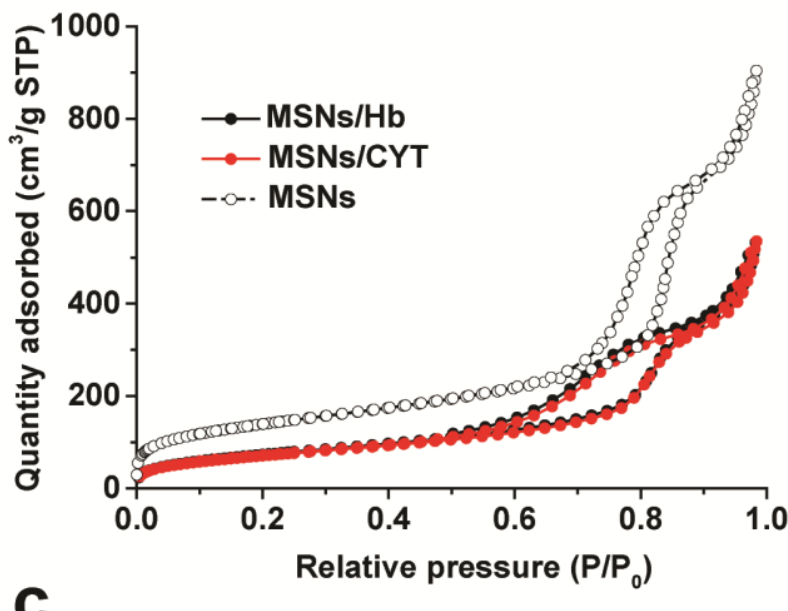

C

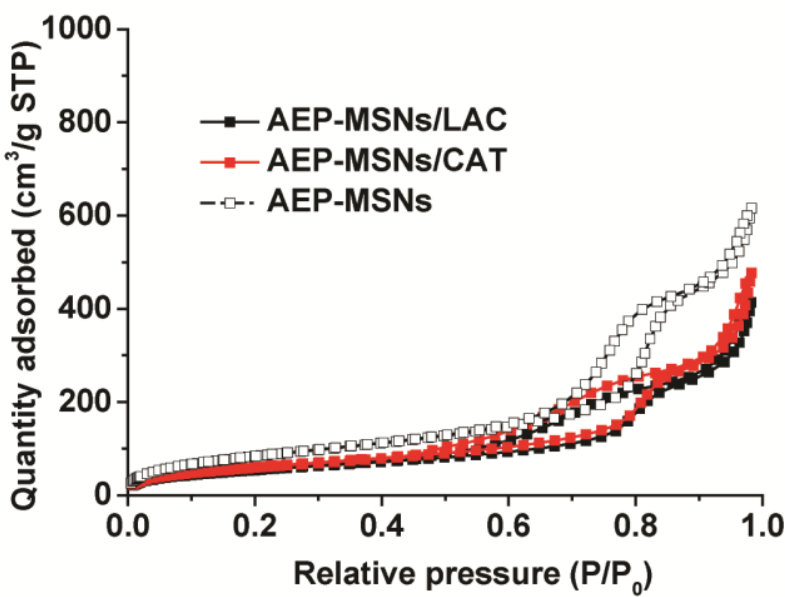

b
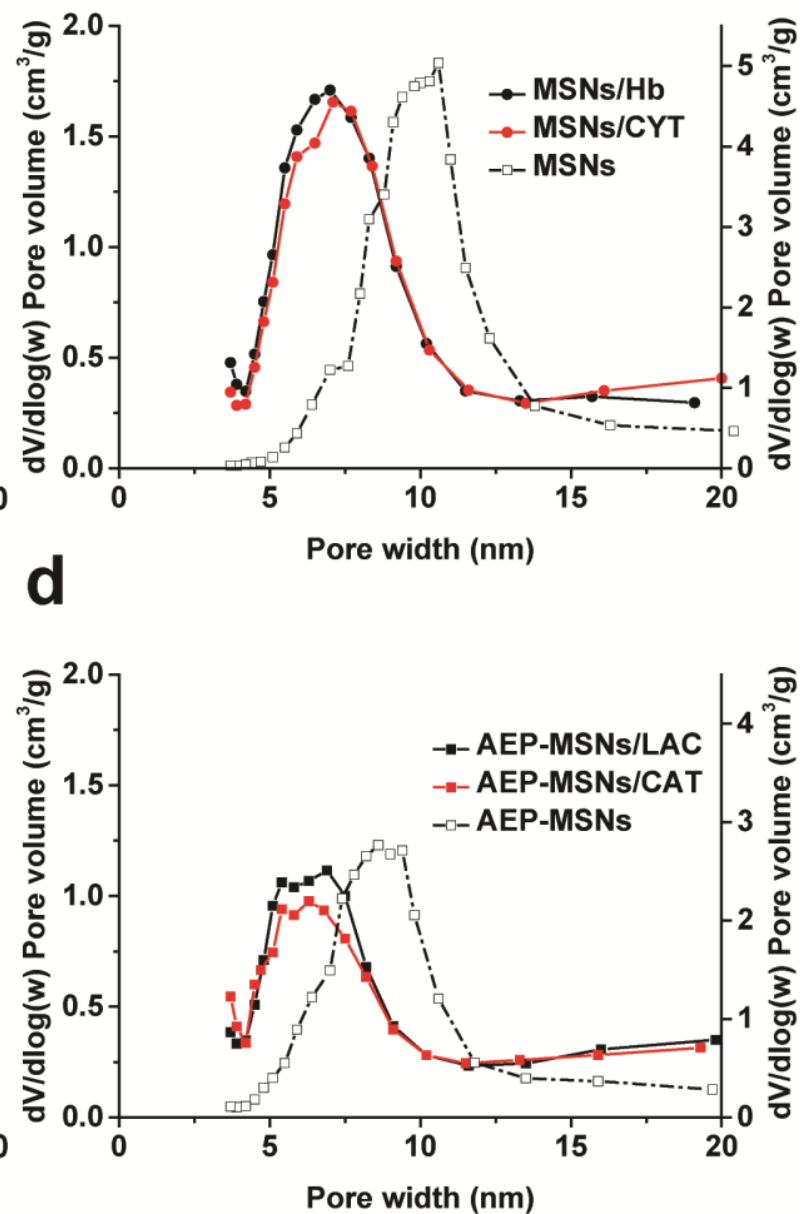

Figure 4. (a) Nitrogen adsorption-desorption isotherms of MSNs/proteins (Hb and CYT), and

(b) corresponding pore size distributions, with MSNs as a control; (c) nitrogen adsorptiondesorption isotherms of AEP-MSNs/proteins (LAC and CAT), and corresponding (d) pore size distributions, with AEP-MSNs as a control.

\subsection{Protein release studies}

The in vitro release of proteins from MSNs or AEP-MSNs was investigated using a high ionic strength (270 mM) PBS buffer. For this study MSNs containing Hb, LYS and CYT, and AEP-MSNs loaded with LAC, OVA, BSA and CAT were tested. All the profiles showed a rapid burst release (Figure 5), ${ }^{74}$ and a direct correlation between the final released percentage and the molecular weight of the protein was observed. 

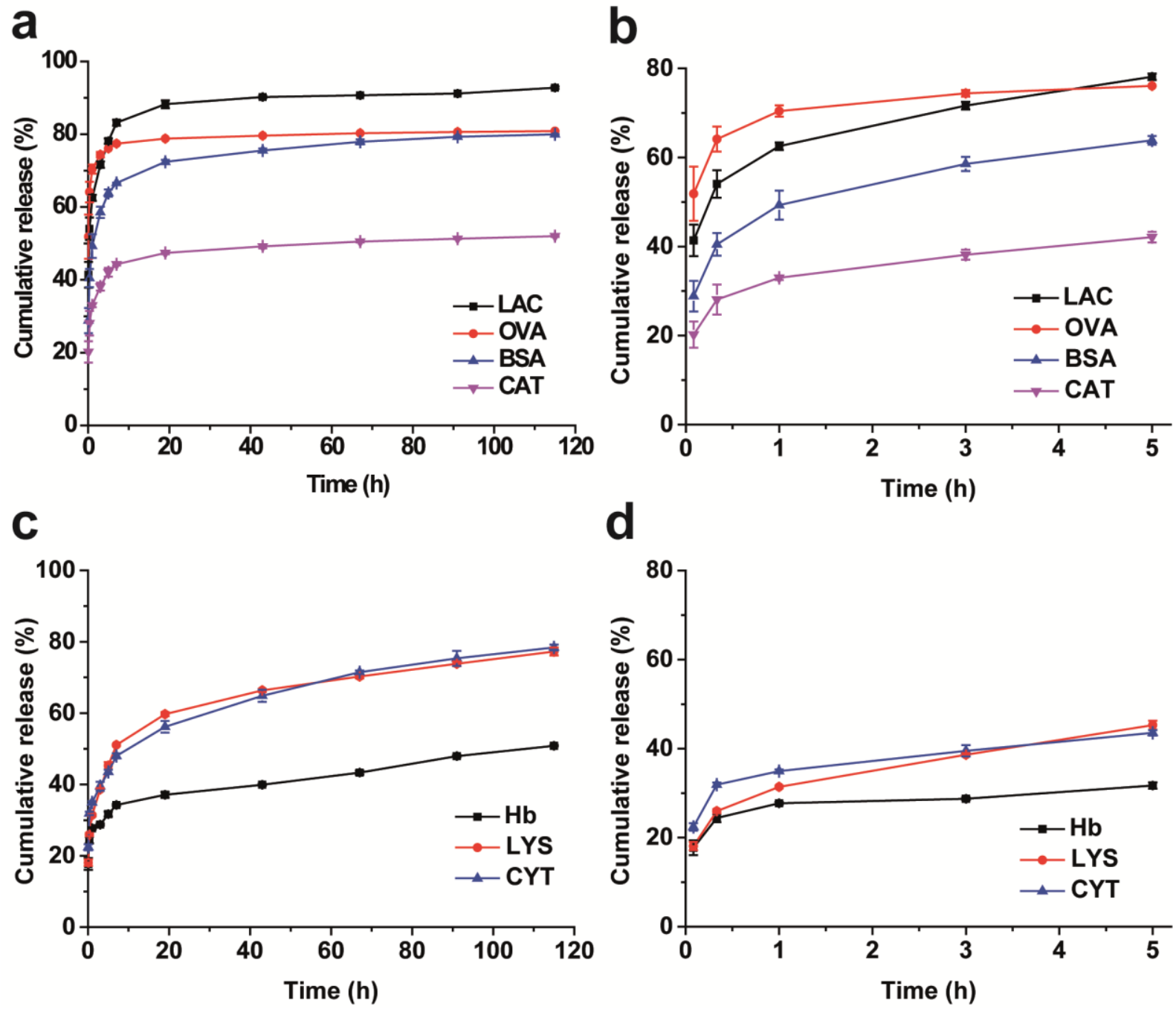

Figure 5. (a) and (b) LAC, OVA, BSA and CAT release profiles from AEP-MSNs and; (c) and (d) $\mathrm{Hb}$, LYS and CYT release profiles from MSNs. Conditions for release of all proteins: PBS, (ionic strength $270 \mathrm{mM}$ ), $37^{\circ} \mathrm{C}$.

A large amount of the encapsulated LAC (93\%) was released from AEP-MSNs. This was the smallest protein to be encapsulated into these MSNs, so it is rational that this shows the highest released percentage as its small size makes 'escape' from the pores easier. OVA and BSA showed comparable release percentages ( 81 and $80 \%$, respectively). These proteins are similar in size, therefore it is unsurprising that the amounts released are similar. They are significantly larger than LAC however, and the high release percentages are encouraging as these reveal that reasonably large proteins can escape from the MSN channels. Only $52 \%$ of 


\section{ACS Applied Materials \& Interfaces}

CAT, the largest protein to be encapsulated in the AEP-MSNs was released however. The dimensions of CAT are $7 \times 8 \times 10 \mathrm{~nm}$, this is close to the diameter of the pores and so it is possible that this protein gets trapped inside the pores resulting in a lower released percentage.

For the proteins encapsulated in the unmodified MSNs, a similar trend was seen. The two smallest proteins, CYT and LYS, exhibited similar release percentages (78 and 77\% respectively). For $\mathrm{Hb}$, the largest protein encapsulated into these MSNs, only $41 \%$ was released over the time frame studied, indicating that size plays an important role in release dynamics in these MSNs as well.

The effect of the ionic strength of the buffer on the proteins' release kinetics was also investigated (Figure S1). Comparison of Figure 5a\&b with Figure S1a\&b clearly shows the effect of ionic strength on the AEP-MSNs encapsulated proteins' release. When a low ionic strength buffer was used, the amount of protein released decreased for all the proteins investigated. The largest decrease was seen for LAC; $93 \%$ of the encapsulated protein was released when PBS with an ionic strength of $270 \mathrm{mM}$ was used, this decreased to $69 \%$ for 166 mM PB buffer and a further decrease to $21 \%$ was observed when PB buffer with $12 \mathrm{mM}$ ionic strength was employed, with the other proteins following a similar trend. These results indicate that a higher ionic strength of the buffer and a smaller molecular weight of the protein results in a larger percentage of released protein. This is likely to be because a smaller protein can escape the channels more easily, and a higher ionic strength buffer, ${ }^{18}$ screens electrostatic interactions more effectively, meaning the electrostatic interactions that are holding the proteins in place in the MSNs are diminished.

The release of the MSN-encapsulated proteins did not follow such a clear trend when the ionic strength of the buffer was changed; compare Figure 5c\&d and S1c\&d. At low ionic strength, the initial release rate of LYS was very low; this increased with an increasing buffer strength, as did the total amount of protein released. $\mathrm{Hb}$ and CYT exhibited different properties however. Both proteins showed burst release kinetics at high ionic strengths, 


\section{ACS Applied Materials \& Interfaces}

whereas at low ionic strength the release was more sustained. The total amount released did not change as much for these proteins upon altering the ionic strength of the buffer $(24,27 \%$, and $51 \%$ for $\mathrm{Hb}$ and $54,69 \%$, and $78 \%$ for CYT at $12 \mathrm{mM}, 166 \mathrm{mM}$, and $270 \mathrm{mM}$ ionic strength respectively) as it did for others. This suggests the factors controlling the release from the negatively-charged MSNs are more subtle than from the AEP-MSNs. Both protein size and charge (distribution) have an effect, but the effects of these are not easily separated. It would be interesting for future work to study the release of more proteins with MSNs to disentangle these effects and to determine which is more important - molecular weight or charge of the protein.

Finally, for any application, it is important that the released proteins are not misfolded, for example, due to strong MSN-protein interactions. Therefore the secondary structure of the released proteins was compared to that of non-encapsulated proteins. The structures were measured using circular dichroism (CD) spectroscopy and no change was seen in any of the protein's secondary structure after encapsulation and release (Figure S2).

\section{Conclusion}

Here we have described a method to synthesize sub-200 nm MSNs with large (10 nm) channels perpendicular to the long axis of the particles. As a result, the MSNs (or the facilely modified AP- and AEP-MSNs) have a rapid, high encapsulation efficiency of a wide range of proteins with vastly different properties. Encapsulation was found to be dependent on the surface chemistry within the channels, and was directly related to the surface charge of the protein. The release of such proteins is tunable, and is dependent on the ionic strength of the release medium and the MSN surface chemistry. Protein properties such as molecular weight and charge also play a role in the release kinetics, with the parameters governing release being more subtle and involved than those controlling encapsulation. 
This novel type of MSN with large channels and therefore a high surface area, resulting in a high encapsulation efficiency and controllable release profiles of proteins enables potential applications in fields such as protein therapy and drug delivery.

\section{ASSCIATED CONTENT}

\section{Supporting Information}

Release profiles of proteins from AEP-MSNs. CD spectra of free and released proteins. Physical characteristics of MSNs and AEP-MSNs. 3D-reconstruction of the MSNs by (cryo-) electron tomography. This materials is available free of charge via the Internet at http://pubs.acs.org.

\section{AUTHOR INFORMATION}

\section{Corresponding Author}

*E-mail address: $\underline{\text { a.kros@ } @ \text { chem.leidenuniv.nl }}$

E-mail address: $\underline{w . j i s k o o t @ l a c d r . l e i d e n u n i v . n l ~}$

\section{Acknowledgements}

JT acknowledges the support from the Chinese Scholarship Council. ALB and JB acknowledge the support of the NWO via VENI grants. Alexander V. Korobko assisted with BET measurements in Delft University of Technology. 


\section{References}

1. Gu, Z.; Biswas, A.; Zhao, M.; Tang, Y., Tailoring nanocarriers for intracellular protein delivery. Chemical Society reviews 2011, 40 (7), 3638-3655.

2. Leader, B.; Baca, Q. J.; Golan, D. E., Protein therapeutics: A summary and pharmacological classification. Nat Rev Drug Discov 2008, 7 (1), 21-39.

3. Lu, Y.; Sun, W. J.; Gu, Z., Stimuli-responsive nanomaterials for therapeutic protein delivery. J Control Release 2014, 194, 1-19.

4. Mitragotri, S.; Burke, P. A.; Langer, R., Overcoming the challenges in administering biopharmaceuticals: formulation and delivery strategies. Nat Rev Drug Discov 2014, 13 (9), 655-672.

5. $\quad$ Epler, K.; Padilla, D.; Phillips, G.; Crowder, P.; Castillo, R.; Wilkinson, D.; Wilkinson, B.; Burgard, C.; Kalinich, R.; Townson, J.; Chackerian, B.; Willman, C.; Peabody, D.;

Wharton, W.; Brinker, C. J.; Ashley, C.; Carnes, E., Delivery of Ricin Toxin A-Chain by Peptide-Targeted Mesoporous Silica Nanoparticle-Supported Lipid Bilayers. Adv Healthc Mater 2012, 1 (3), 348-353.

6. Zhao, M. X.; Hu, B. L.; Gu, Z.; Joo, K. I.; Wang, P.; Tang, Y., Degradable polymeric nanocapsule for efficient intracellular delivery of a high molecular weight tumor-selective protein complex. Nano Today 2013, 8 (1), 11-20.

7. Mahony, D.; Cavallaro, A. S.; Stahr, F.; Mahony, T. J.; Qiao, S. Z.; Mitter, N., Mesoporous silica nanoparticles act as a self-adjuvant for ovalbumin model antigen in mice. Small 2013, 9 (18), 3138-3146.

8. $\quad$ Li, D. D.; Kordalivand, N.; Fransen, M. F.; Ossendorp, F.; Raemdonck, K.; Vermonden, T.; Hennink, W. E.; van Nostrum, C. F., Reduction-Sensitive Dextran Nanogels Aimed for Intracellular Delivery of Antigens. Adv Funct Mater 2015, 25 (20), 2993-3003.

9. Chang, F. P.; Chen, Y. P.; Mou, C. Y., Intracellular implantation of enzymes in hollow silica nanospheres for protein therapy: cascade system of superoxide dismutase and catalase. Small 2014, 10 (22), 4785-4795.

10. Shuvaev, V. V.; Muzykantov, V. R., Targeted modulation of reactive oxygen species in the vascular endothelium. J Control Release 2011, 153 (1), 56-63.

11. Wang, M.; Zuris, J. A.; Meng, F. T.; Rees, H.; Sun, S.; Deng, P.; Han, Y.; Gao, X.; Pouli, D.; Wu, Q.; Georgakoudi, I.; Liu, D. R.; Xu, Q. B., Efficient delivery of genomeediting proteins using bioreducible lipid nanoparticles. P Natl Acad Sci USA 2016, 113 (11), 2868-2873.

12. Ghosh, P.; Yang, X. C.; Arvizo, R.; Zhu, Z. J.; Agasti, S. S.; Mo, Z. H.; Rotello, V. M., Intracellular Delivery of a Membrane-Impermeable Enzyme in Active Form Using Functionalized Gold Nanoparticles. J Am Chem Soc 2010, 132 (8), 2642-2645.

13. Vermonden, T.; Censi, R.; Hennink, W. E., Hydrogels for protein delivery. Chem Rev 2012, 112 (5), 2853-2888.

14. Tarn, D.; Ashley, C. E.; Xue, M.; Carnes, E. C.; Zink, J. I.; Brinker, C. J., Mesoporous Silica Nanoparticle Nanocarriers: Biofunctionality and Biocompatibility. Accounts Chem Res 2013, 46 (3), 792-801.

15. Argyo, C.; Weiss, V.; Bräuchle, C.; Bein, T., Multifunctional Mesoporous Silica Nanoparticles as a Universal Platform for Drug Delivery. Chemistry of Materials 2014, 26 (1), 435-451.

16. Lee, C.-H.; Lin, T.-S.; Mou, C.-Y., Mesoporous materials for encapsulating enzymes. Nano Today 2009, 4 (2), 165-179.

17. Yang, P.; Gai, S.; Lin, J., Functionalized mesoporous silica materials for controlled drug delivery. Chemical Society reviews 2012, 41 (9), 3679-3698.

18. Han, Y.-J.; Stucky, G. D.; Butler, A., Mesoporous silicate sequestration and release of proteins. J Am Chem Soc 1999, 121 (42), 9897-9898. 
19. Diaz, J. F.; Balkus, K. J., Enzyme immobilization in MCM-41 molecular sieve. J Mol Catal B-Enzym 1996, 2 (2-3), 115-126.

20. Porta, F.; Lamers, G. E. M.; Zink, J. I.; Kros, A., Peptide modified mesoporous silica nanocontainers. Phys. Chem. Chem. Phys. 2011, 13 (21), 9982-9985.

21. Martelli, G.; Zope, H. R.; Capell, M. B.; Kros, A., Coiled-coil peptide motifs as thermoresponsive valves for mesoporous silica nanoparticles. Chemical communications 2013, 49 (85), 9932-9934.

22. Knezevic, N. Z.; Durand, J. O., Targeted Treatment of Cancer with Nanotherapeutics Based on Mesoporous Silica Nanoparticles. Chempluschem 2015, 80 (1), 26-36.

23. Ma, M.; Chen, H. R.; Chen, Y.; Zhang, K.; Wang, X.; Cui, X. Z.; Shi, J. L., Hyaluronic acid-conjugated mesoporous silica nanoparticles: excellent colloidal dispersity in physiological fluids and targeting efficacy. J Mater Chem 2012, 22 (12), 5615-5621.

24. Porta, F.; Lamers, G. E. M.; Morrhayim, J.; Chatzopoulou, A.; Schaaf, M.; den Dulk, H.; Backendorf, C.; Zink, J. I.; Kros, A., Folic Acid-Modified Mesoporous Silica Nanoparticles for Cellular and Nuclear Targeted Drug Delivery. Adv Healthc Mater 2013, 2 (2), 281-286.

25. Sang, L. C.; Vinu, A.; Coppens, M. O., General Description of the Adsorption of Proteins at Their Iso-electric Point in Nanoporous Materials. Langmuir 2011, 27 (22), 1382813837.

26. Xu, C.; Yu, M. H.; Noonan, O.; Zhang, J.; Song, H.; Zhang, H. W.; Lei, C.; Niu, Y. T.; Huang, X. D.; Yang, Y. N.; Yu, C. Z., Core-Cone Structured Monodispersed Mesoporous Silica Nanoparticles with Ultra-large Cavity for Protein Delivery. Small 2015, 11 (44), 59495955.

27. Chen, Y. P.; Chen, C. T.; Hung, Y.; Chou, C. M.; Liu, T. P.; Liang, M. R.; Chen, C. T.; Mou, C. Y., A New Strategy for Intracellular Delivery of Enzyme Using Mesoporous Silica Nanoparticles: Superoxide Dismutase. J Am Chem Soc 2013, 135 (4), 1516-1523. 28. Sharif, F.; Porta, F.; Meijer, A. H.; Kros, A.; Richardson, M. K., Mesoporous silica nanoparticles as a compound delivery system in zebrafish embryos. Int. J. Nanomed. 2012, 7 , 1875-1890.

29. Mody, K. T.; Popat, A.; Mahony, D.; Cavallaro, A. S.; Yu, C.; Mitter, N., Mesoporous silica nanoparticles as antigen carriers and adjuvants for vaccine delivery. Nanoscale 2013, 5 (12), 5167-5179.

30. Cai, Z. W.; Ye, Z. M.; Yang, X. W.; Chang, Y. L.; Wang, H. F.; Liu, Y. F.; Cao, A. N., Encapsulated enhanced green fluorescence protein in silica nanoparticle for cellular imaging. Nanoscale 2011, 3 (5), 1974-1976.

31. Slowing, I. I.; Vivero-Escoto, J. L.; Wu, C. W.; Lin, V. S. Y., Mesoporous silica nanoparticles as controlled release drug delivery and gene transfection carriers. Adv Drug Deliver Rev 2008, 60 (11), 1278-1288.

32. Martens, T. F.; Remaut, K.; Demeester, J.; De Smedt, S. C.; Braeckmans, K., Intracellular delivery of nanomaterials: How to catch endosomal escape in the act. Nano Today 2014, 9 (3), 344-364.

33. Moller, K.; Kobler, J.; Bein, T., Colloidal suspensions of nanometer-sized mesoporous silica. Adv Funct Mater 2007, 17 (4), 605-612.

34. Han, Y.; Ying, J. Y., Generalized fluorocarbon-surfactant-mediated synthesis of nanoparticles with various mesoporous structures. Angew Chem Int Edit 2005, 44 (2), 288292.

35. Wu, S. H.; Mou, C. Y.; Lin, H. P., Synthesis of mesoporous silica nanoparticles. Chemical Society reviews 2013, 42 (9), 3862-3875.

36. Nandiyanto, A. B. D.; Kim, S.-G.; Iskandar, F.; Okuyama, K., Synthesis of spherical mesoporous silica nanoparticles with nanometer-size controllable pores and outer diameters. Microporous and Mesoporous Materials 2009, 120 (3), 447-453. 
37. Sun, J.; Zhang, H.; Tian, R.; Ma, D.; Bao, X.; Su, D. S.; Zou, H., Ultrafast enzyme immobilization over large-pore nanoscale mesoporous silica particles. Chemical communications 2006, (12), 1322-1324.

38. Hartmann, M., Ordered mesoporous materials for bioadsorption and biocatalysis. Chemistry of Materials 2005, 17 (18), 4577-4593.

39. Katiyar, A.; Ji, L.; Smirniotis, P. G.; Pinto, N. G., Adsorption of bovine serum albumin and lysozyme on siliceous MCM-41. Microporous and Mesoporous Materials 2005, 80 (1-3), 311-320.

40. Hudson, S.; Cooney, J.; Magner, E., Proteins in mesoporous silicates. Angewandte Chemie 2008, 47 (45), 8582-8594.

41. Fan, J.; Lei, J.; Wang, L.; Yu, C.; Tu, B.; Zhao, D., Rapid and high-capacity immobilization of enzymes based on mesoporous silicas with controlled morphologies. Chemical communications 2003, (17), 2140-2141.

42. Knezevic, N. Z.; Durand, J. O., Large pore mesoporous silica nanomaterials for application in delivery of biomolecules. Nanoscale 2015, 7 (6), 2199-2209.

43. Shin, H. S.; Hwang, Y. K.; Huh, S., Facile Preparation of Ultra-Large Pore Mesoporous Silica Nanoparticles and Their Application to the Encapsulation of Large Guest Molecules. Acs Appl Mater Inter 2014, 6 (3), 1740-1746.

44. Lu, F.; Wu, S. H.; Hung, Y.; Mou, C. Y., Size Effect on Cell Uptake in WellSuspended, Uniform Mesoporous Silica Nanoparticles. Small 2009, 5 (12), 1408-1413.

45. Vivero-Escoto, J. L.; Slowing, II; Trewyn, B. G.; Lin, V. S., Mesoporous silica nanoparticles for intracellular controlled drug delivery. Small 2010, 6 (18), 1952-1967. 46. Zhao, D. Y.; Feng, J. L.; Huo, Q. S.; Melosh, N.; Fredrickson, G. H.; Chmelka, B. F.; Stucky, G. D., Triblock copolymer syntheses of mesoporous silica with periodic 50 to 300 angstrom pores. Science 1998, 279 (5350), 548-552.

47. Han, Y.; Li, D. F.; Zhao, L.; Song, J. W.; Yang, X. Y.; Li, N.; Di, Y.; Li, C. J.; Wu, S.; Xu, X. Z.; Meng, X. J.; Lin, K. F.; Xiao, F. S., High-temperature generalized synthesis of stable ordered mesoporous silica-based materials by using fluorocarbon-hydrocarbon surfactant mixtures. Angew Chem Int Edit 2003, 42 (31), 3633-3637.

48. Yu, Q. Y.; Hui, J. F.; Wang, P. P.; Xu, B.; Zhuang, J.; Wang, X., Hydrothermal synthesis of mesoporous silica spheres: effect of the cooling process. Nanoscale 2012, 4 (22), 7114-7120.

49. Hartono, S. B.; Phuoc, N. T.; Yu, M. H.; Jia, Z. F.; Monteiro, M. J.; Qiao, S. H.; Yu, C. Z., Functionalized large pore mesoporous silica nanoparticles for gene delivery featuring controlled release and co-delivery. J Mater Chem B 2014, 2 (6), 718-726.

50. Zhang, H.; Sun, J. M.; Ma, D.; Bao, X. H.; Klein-Hoffmann, A.; Weinberg, G.; Su, D. S.; Schlogl, R., Unusual mesoporous SBA-15 with parallel channels running along the short axis. J Am Chem Soc 2004, 126 (24), 7440-7441.

51. Vinu, A.; Murugesan, V.; Tangermann, O.; Hartmann, M., Adsorption of cytochrome $\mathrm{c}$ on mesoporous molecular sieves: Influence of $\mathrm{pH}$, pore diameter, and aluminum incorporation. Chemistry of Materials 2004, 16 (16), 3056-3065.

52. Wang, Y.; Caruso, F., Enzyme encapsulation in nanoporous silica spheres. Chemical communications 2004, (13), 1528-1529.

53. Urabe, Y.; Shiomi, T.; Itoh, T.; Kawai, A.; Tsunoda, T.; Mizukami, F.; Sakaguchi, K., Encapsulation of hemoglobin in mesoporous silica (FSM)-enhanced thermal stability and resistance to denaturants. Chembiochem 2007, 8 (6), 668-674.

54. Wang, Y. J.; Caruso, F., Mesoporous silica spheres as supports for enzyme immobilization and encapsulation. Chemistry of Materials 2005, 17 (5), 953-961.

55. Zhang, Y.; Zhi, Z.; Jiang, T.; Zhang, J.; Wang, Z.; Wang, S., Spherical mesoporous silica nanoparticles for loading and release of the poorly water-soluble drug telmisartan. $J$ Control Release 2010, 145 (3), 257-263. 
56. Ashley, C. E.; Carnes, E. C.; Phillips, G. K.; Padilla, D.; Durfee, P. N.; Brown, P. A.; Hanna, T. N.; Liu, J.; Phillips, B.; Carter, M. B.; Carroll, N. J.; Jiang, X.; Dunphy, D. R.; Willman, C. L.; Petsev, D. N.; Evans, D. G.; Parikh, A. N.; Chackerian, B.; Wharton, W.; Peabody, D. S.; Brinker, C. J., The targeted delivery of multicomponent cargos to cancer cells by nanoporous particle-supported lipid bilayers. Nature materials 2011, 10 (5), 389-397.

57. Gao, W.; Sha, B. Y.; Zou, W.; Liang, X.; Meng, X. Z.; Xu, H.; Tang, J.; Wu, D. C.; Xu, L. X.; Zhang, H., Cationic amylose-encapsulated bovine hemoglobin as a nanosized oxygen carrier. Biomaterials 2011, 32 (35), 9425-9433.

58. Barrett, E. P. J., L. E.; HALENDA, P., The determination of pore volume and area distributions in porous substances. I. Computations from nitrogen isotherms $J$ Am Chem Soc 1951, 73, 373-380.

59. Slowing, I. I.; Trewyn, B. G.; Lin, V. S. Y., Mesoporous silica nanoparticles for intracellular delivery of membrane-impermeable proteins. J Am Chem Soc 2007, 129 (28), 8845-8849.

60. Kresge, C. T.; Leonowicz, M. E.; Roth, W. J.; Vartuli, J. C.; Beck, J. S., Ordered Mesoporous Molecular-Sieves Synthesized by a Liquid-Crystal Template Mechanism. Nature 1992, 359 (6397), 710-712.

61. Areva, S.; Boissiere, C.; Grosso, D.; Asakawa, T.; Sanchez, C.; Linden, M., One-pot aerosol synthesis of ordered hierarchical mesoporous core-shell silica nanoparticles. Chemical communications 2004, (14), 1630-1631.

62. Matos, J. R.; Kruk, M.; Mercuri, L. P.; Jaroniec, M.; Zhao, L.; Kamiyama, T.; Terasaki, O.; Pinnavaia, T. J.; Liu, Y., Ordered mesoporous silica with large cage-like pores: Structural identification and pore connectivity design by controlling the synthesis temperature and time. J Am Chem Soc 2003, 125 (3), 821-829.

63. Pan, D. H.; Yuan, P.; Zhao, L. Z.; Liu, N. A.; Zhou, L.; Wei, G. F.; Zhang, J.; Ling, Y. C.; Fan, Y.; Wei, B. Y.; Liu, H. Y.; Yu, C. Z.; Bao, X. J., New Understanding and Simple Approach to Synthesize Highly Hydrothermally Stable and Ordered Mesoporous Materials. Chemistry of Materials 2009, 21 (22), 5413-5425.

64. Ito, T.; Sun, L.; Bevan, M. A.; Crooks, R. M., Comparison of nanoparticle size and electrophoretic mobility measurements using a carbon-nanotube-based coulter counter, dynamic light scattering, transmission electron microscopy, and phase analysis light scattering. Langmuir 2004, 20 (16), 6940-6945.

65. Schmidt, R.; Hansen, E. W.; Stocker, M.; Akporiaye, D.; Ellestad, O. H., Pore-Size Determination of Mcm-41 Mesoporous Materials by Means of H-1-Nmr Spectroscopy, N-2 Adsorption, and Hrem - a Preliminary-Study. J Am Chem Soc 1995, 117 (14), 4049-4056. 66. Duan, L.; Yan, X. H.; Wang, A. H.; Jia, Y.; Li, J. B., Highly Loaded Hemoglobin Spheres as Promising Artificial Oxygen Carriers. Acs Nano 2012, 6 (8), 6897-6904.

67. Mendez, J.; Morales Cruz, M.; Delgado, Y.; Figueroa, C. M.; Orellano, E. A.; Morales, M.; Monteagudo, A.; Griebenow, K., Delivery of chemically glycosylated cytochrome c immobilized in mesoporous silica nanoparticles induces apoptosis in HeLa cancer cells. Molecular pharmaceutics 2014, 11 (1), 102-111.

68. Hamborg, M.; Rose, F.; Jorgensen, L.; Bjorklund, K.; Pedersen, H. B.; Christensen, D.; Foged, C., Elucidating the mechanisms of protein antigen adsorption to the CAF/NAF liposomal vaccine adjuvant systems: effect of charge, fluidity and antigen-to-lipid ratio. Biochimica et biophysica acta 2014, 1838 (8), 2001-2010.

69. Meder, F.; Brandes, C.; Treccani, L.; Rezwan, K., Controlling protein-particle adsorption by surface tailoring colloidal alumina particles with sulfonate groups. Acta biomaterialia 2013, 9 (3), 5780-5787.

70. Ambati, J.; Lopez, A. M.; Cochran, D.; Wattamwar, P.; Bean, K.; Dziubla, T. D.; Rankin, S. E., Engineered silica nanocarriers as a high-payload delivery vehicle for antioxidant enzymes. Acta biomaterialia 2012, 8 (6), 2096-2103. 
71. Wu, J.; Li, X.; Yan, Y.; Hu, Y.; Zhang, Y.; Tang, Y., Protein adsorption onto nanozeolite: effect of micropore openings. J Colloid Interface Sci 2013, 406, 130-138.

72. Hartono, S. B.; Qiao, S. Z.; Jack, K.; Ladewig, B. P.; Hao, Z. P.; Lu, G. Q., Improving Adsorbent Properties of Cage-like Ordered Amine Functionalized Mesoporous Silica with Very Large Pores for Bioadsorption. Langmuir 2009, 25 (11), 6413-6424.

73. Ravindra, R.; Shuang, Z.; Gies, H.; Winter, R., Protein encapsulation in mesoporous silicate: The effects of confinement on protein stability, hydration, and volumetric properties. J Am Chem Soc 2004, 126 (39), 12224-12225.

74. Chiavazzo, E.; Fasano, M.; Asinari, P.; Decuzzi, P., Scaling behaviour for the water transport in nanoconfined geometries. Nat Commun 2014, 5, 4565. 
ACS Applied Materials \& Interfaces

\section{Graphical abstract}

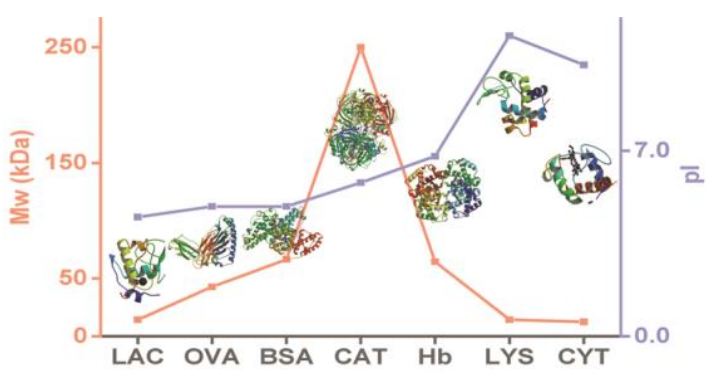

A new type of mesoporous silica nanoparticles is able to encapsulate and release a range of proteins. 